\title{
Determining the economic value of game farm tourism
}

\author{
P. Van Der Merwe, and M. SaAyman
}

Van der Merwe, P. and M. Saayman. 2003. Determining the economic value of game farm tourism. Koedoe 46(2): 103-112. Pretoria. ISSN 0075-6458.

\begin{abstract}
Internationally tourism is accepted as one of the world's fastest-growing industries. The World Tourism Organisation (WTO) indicated that tourist arrivals in 1998 grew by $2.4 \%$ worldwide. The WTO has forecast that the number of people travelling internationally will increase from 613 million in 1997 to 1.6 billion by the year 2020. Ecotourism, which according to the WTO is any form of tourism to an unspoilt nature area, is responsible for $20 \%$ of the world's total tourism expenditure and is also rated the fastest growing of all tourism sectors. It is also a fact that $80 \%$ of nature conservation in South Africa is taking place on privately owned land such as game farms, and this forms part of ecotourism. The above endorses that ecotourism is an important product for South Africa and a drawcard for international as well as local tourists. The main objective of this study was to determine the economic value of game farm tourism. This will be done by determining the economic value of each of the four pillars on which game farming is based, namely hunting, ecotourism, breeding rare game species and venison sales. Data collation was done in two ways. Firstly, research was conducted in the form of questionnaires. Game farms were randomly sampled from the database of registered game farms. The aim of this questionnaire was threefold and determined the economic contribution of game farm tourism to ecotourism. Secondly, a literature study was conducted that included the latest data by PHASA (Professional Hunters Association of South Africa), Nature Conservation and trophy hunting in South Africa. This paper will argue that game farm tourism makes a significant economic contribution to the economy of South Africa, apart from the substantial economic contribution game farm tourism already makes to conservation. This paper will be organised as follows: The first section deals with the introduction, which indicates the growth of game farm tourism; the second section explains the methodology; the third section discusses the results; and the last section concludes the paper.
\end{abstract}

Key words: ecotourism, economic contribution, hunting, game farm tourism.

P. Merwe, and M. Saayman, Institute for Tourism and Leisure Studies, Potchefstroom University for CHE, Private Bag x 6001, Potchefstroom, 2520 Republic of South Africa (ontpvdm@puknet.puk.ac.za; ontms@puknet.puk.ac.za

\section{Introduction}

Tourism has been accepted by the South African government, business and labour as one of the key drivers for the creation of wealth and economic empowerment (GCIS 1999). This is supported by the fact that internationally tourism is acknowledge as one of the world's fastest-growing industries (Shaw \& Williams 1994; Cooper et al. 1993; Kerzner 1995; Anon 1998). As further support to the latter, the World Tourism Organi- sation (WTO) forecasts that the number of people travelling internationally would increase to 1.6 billion by the year 2020 (World Bank 1998; WTO 1998, 2001a). If the target as predicted by the WTO is reached it would result in an increase in the next seventeen years of almost $\$ 2000$ billion a year (Van Zyl 2000).

Fraser (1999) forecasts that South Africa's tourism industry will grow by more than $5.5 \%$ between 1998 and 2010, which is bet- 
ter than the predicted $4.1 \%$ of the global market. It is also estimated that arrivals will increase from 6 million international tourists arrivals in 2000 to 30.5 million in 2020 (WTO 2001b). The African continent can treble the size of its tourism industry by 2020 if proper efforts are made. This will result in forecast tourist arrivals of 77.3 million to Africa. On the African continent, South Africa attracts the most overseas tourists, which makes tourism one of the largest industries in South Africa (WTO 2001b). Research indicated that tourism in South Africa contributed approximately $4.6 \%$ to the Gross Domestic Product (GDP) the past four years. In 2002 tourism arrivals increased by $16 \%$ ranking it one of the highest growth rates in the world (Thornton \& Feinstein 2002; GCIS 1998).

For the overseas as well as local tourists scenic beauty and wildlife remain the major tourism attractions that South Africa has to offer (GCIS 1998; GCIS 1999). It is a fact that $80 \%$ of nature conservation in South Africa is taking place on privately owned land such as game farms (Eloff 2000; Fox \& Du Plessis 2000), and according to Bothma (2002) there was a $2.5 \%$ increase in land utilised for game farming from 1998 to 1999. The latter translates into a 300000 ha per year increase for the purpose of game farming tourism. Flack (2002a) states that it is estimated that the conversion rate from cattle to game farming in 2002 was nearly 500000 ha, which is 200000 ha more than the 1998 to 1999 increase. Table 1 indicates the number of exempted game farms in South Africa (exempted in this context implies that these game farms have permission to hunt within their boundaries), as well as the surface area.

From Table 1 it is clear that the Limpopo Province has the most game farms (2 484), followed by the Northern Cape (986) and thirdly the Eastern Cape (624). When considering the total surface area that is exempted, the Northern Cape outperforms the other provinces by 4852053 ha. The reason for this is that the Northern Cape's carrying capacity is lower, therefore more land is needed for the same number of head of game as for example in the Eastern Cape.

In 2000, it was estimated that there were 7000 privately owned game farms in South Africa with a total surface area of 16 million ha (Ebedes 2002), of which only 5061 were exempted game farms, with a surface area of 10364154 ha (Erasmus 2000). Research conducted in 1993 indicated that the surface area of exempted game farms constituted $8.5 \%$ of the total agricultural land in South Africa, which increased to $12.5 \%$ in 2000 , with a total of 1.7 million head of game (Eloff 2002a; Erasmus 2000). The 2002

Table 1

Number of exempted game farms in South Africa

\begin{tabular}{lcccc}
\hline $\begin{array}{l}\text { Province(Year } \\
\text { 2000) }\end{array}$ & $\begin{array}{c}\text { Number of exempted } \\
\text { game farms }\end{array}$ & $\begin{array}{c}\text { Surface area of } \\
\text { exempted farms }\end{array}$ & $\begin{array}{c}\% \text { of exempted } \\
\text { farms }\end{array}$ & $\begin{array}{c}\% \text { of exempted farms } \\
\text { according to hectares }\end{array}$ \\
\hline Free State & 180 & 147743 & $3.56 \%$ & $1.43 \%$ \\
Limpopo & 2482 & 3325652 & $49.04 \%$ & $32.10 \%$ \\
North West & 340 & 364935 & $6.72 \%$ & $3.51 \%$ \\
Mpumalanga & 205 & 276016 & $4.05 \%$ & $2.66 \%$ \\
Gauteng & 72 & 82076 & $1.42 \%$ & $0.79 \%$ \\
Kwa Zulu-Natal & 90 & 168841 & $1.78 \%$ & $1.63 \%$ \\
Eastern Cape & 624 & $485630.51 \%$ & $46.81 \%$ \\
Northern Cape & 986 & 65205 & $12.33 \%$ & $2.56 \%$ \\
Western Cape & 82 & 10364154 & $1.48 \%$ & $100 \%$ \\
\hline Total & 5061 & $100 \%$ & $100 \%$ \\
\hline
\end{tabular}

Source: Eloff 2002a 
statistics showed that $13.3 \%$ of the agricultural land was used for game farming, while national and provincial game reserves only covered $6 \%$ or 6.1 million ha of land in South Africa (Flack 2002; Van der Walt 2002). If one adds up the total land used for wildlife tourism it is almost $20 \%$ of South Africa's total surface area.

As a significant surface area is set aside for the purpose of game farm tourism, the question arises whether this is productive land use. Therefore the aim of this paper is to determine the economic value of game farm tourism in South Africa, and to achieve the aim the paper is organised in four sections. The first section deals with an overview of game farm tourism. In the second section the methodology is discussed, and thirdly the economic value of the four pillars of game farm tourism is analysed. Section four sets out the conclusions about the economic value of game farm tourism drawn from the study.

\section{Methods}

Methodology used in this research consists of a literature study and a survey.

\section{Literature study}

The literature study was done in order to collate the latest data on game farm tourism provided by PHASA (Professional Hunters Association of South Africa), Nature Conservation and trophy hunting in South Africa respectively. In other words all existing data, which included the growth of hunting and game sales, were consulted. Previous research done in the Eastern Cape on game farms was also included (Radder et al. 2000). The literature study was done to determine the economic value of the four pillars of game farm tourism, which include breeding of rare game species and live game sales, hunting, processed game products and ecotourism expenditure (Van der Merwe \& Saayman 2002), and these are described next.

Breeding of scarce game species and live game sales

Eloff (1999) describes game farming with scarce game species as game farming where the emphasis is more on the production of the scarce game species with the aim of selling them again to other game farmers. Animals that are classified as scarce game species include buffalo, black rhino, sable antelope and the endangered roan antelope, just to name but a few. Live game sales or auctions imply the selling of game (endangered and not endangered) at auctions. Here farmers have an opportunity to bid on game species that they are interested in.

\section{Hunting}

Hunting is defined by nature conservation as follows: In relation to any wild animal, it means by any means whatsoever to hunt or search for, to kill, capture or attempt to kill or capture, or pursue, follow or drive with intent to kill or capture, or to shoot at, poison, lie and wait for or wilfully disturb (Eastern Cape Province 1974). Hunting can be broken down into trophy hunting, biltong hunting, bow hunting and bird hunting. However, for the purpose of this paper only trophy hunting and biltong hunting (of which bow hunting forms part) will be discussed. The reason is that hunting is the single biggest economic contributor to game farm tourism.

Processed game products

Venison or game products are currently mentioned regularly as potential market resources for game farm owners in South Africa (Bothma 2002). Processed game products imply that excess game is killed for their meat (venison) to produce meat products such as, biltong, salami, chilli bites, dry wors and venison for restaurants.

\section{Ecotourism}

Koch (1995) describes ecotourism as 'purposeful travel to natural areas to understand the cultural and natural history of the environment, taking care not to alter the integrity of the ecosystem, and producing economic opportunities that make conservation of natural resources beneficial to local people'. Van Wyk (1995) defines ecotourism as 'an enlightening nature travel experience that contributes to conservation of the ecosystem, while respecting the integrity of the host'. The latter emphasises the concept of an experience. This forms the backbone of tourism and tourism products should be developed in order to provide for a special experience.

The following are some ecotourism activities that can be provided to tourists on a game farm:

hiking trails, bird watching, photographic safaris, $4 \times 4$ trails, canoeing and abseiling for more adventurous tourists; conference facilities;

promotion of unusual attractions, like caves, bushmen paintings, waterfalls and ruins of previous civilisations; 
Table 2

Auction sales over past ten years

\begin{tabular}{lcrcr}
\hline Year & $\begin{array}{c}\text { Number of } \\
\text { game sold }\end{array}$ & $\begin{array}{c}\text { \% change from } \\
\text { previous year }\end{array}$ & $\begin{array}{c}\text { Turnover } \\
\text { (tax excluded) }\end{array}$ & $\begin{array}{c}\text { \% change from } \\
\text { previous year } \\
\text { in terms of turnover }\end{array}$ \\
\hline 1991 & 8292 & $(+) 15 \%$ & 8999871 & \\
1992 & 9546 & $(+) 19.93 \%$ & 10059969 & $(+) 20.66 \%$ \\
1993 & 11499 & $(-) 3.08 \%$ & 11732596 & $(+) 8.04 \%$ \\
1994 & 11096 & $(-) 17.35 \%$ & 14335805 & $(-) 0.23 \%$ \\
1995 & 9171 & $(+) 23.65 \%$ & 26559557 & $(+) 22.47 \%$ \\
1996 & 11340 & $(+) 6.5 \%$ & 28526052 & $(+) 85.26 \%$ \\
1997 & 12077 & $(+) 18.85 \%$ & 40017964 & $(+) 7.4 \%$ \\
1998 & 14354 & $(+) 7.67 \%$ & 53705823 & $(+) 40.29 \%$ \\
1999 & 15455 & $(+) 14.54 \%$ & 62960451 & $(+) 34.2 \%$ \\
2000 & 17702 & $(-) 2.37 \%$ & 87000473 & $(+) 17.23 \%$ \\
2001 & 17282 & $(+) 15.85 \%$ & 105192180 & $(+) 38.18 \%$ \\
2002 & 20022 & & & \\
\hline
\end{tabular}

Source: Eloff 2003

hot-air balloon trips, horse safaris, walking safaris, mountain bike trails and donkey cart trips; and

educational tours where the tourist can learn more about nature, which means it does not have to include the big five (Van der Merwe \& Saayman 2002).

\section{Survey}

Secondly, research was conducted in the form of questionnaires. Game farms were randomly sampled from the database of the North West Parks and Tourism Board. Two surveys were conducted, one among game farm owners and one among tourists visiting game farms.

Of the 340 exempted game farms in the North West Province (according to the North West Parks and Tourism Board's database) it was decided to select every ninth game farm in order to obtain a $10 \%$ sample. These game farms were then visited in person during July 2002, and all questionnaires were hand-delivered and collected.

The second questionnaire targeted tourists visiting a game farm. A random sample was also drawn from the database of the North West Parks and Tourism Board, of which ten game farms were prepared to participate in the research. The criterion used was that these game farms had to have a well-developed tourism infrastructure. The latter includes proper accommodation and ecotourism facilities in order to attract tourists. An average of five questionnaires per game farm were personally handed out to visitors during the weekends of 30 August and 6 September 2002. $50(n=50)$ questionnaires were received back from the respondents. Research by Radder et al. (2000) done in the Eastern Cape was also used. Radder et al. (2000) conducted a survey of 616 questionnaires among local hunters, 107 of which could be used $(17.4 \%$ response rate)

\section{Results}

The results as mentioned earlier will be based on the four pillars of game farm tourism, namely hunting, breeding scarce game species and live game sales, processed game products and ecotourism expenditure in order to achieve the aim of the study.

\section{Breeding scarce species of game and live animal sales}

Live game sales and the breeding of scarce species are the second biggest generator of revenue for game farm tourism. During the 2000 season live game sales generated R180 million of the gross income of the South African game farm industry (Eloff 2002a; Eloff 2003). This represents a total of game sales and not only sales at auctions. Analysis of game auctions over the past ten years revealed an average increase of $9 \%$ per year. 
Table 3

Percentage price increase (+) or decrease (-) in average auctioned game prices over the past ten years

\begin{tabular}{|c|c|c|c|}
\hline Species & $\begin{array}{l}\% \text { price increase } \\
\text { in ten years }\end{array}$ & $\begin{array}{l}\text { Average } \% \text { price } \\
\text { increase per year } \\
\text { in ten years }\end{array}$ & $\begin{array}{c}\% \text { increase }(+) \text { or } \\
\text { decrease (-) in } 2000 \\
\text { compared with } 1999\end{array}$ \\
\hline Roan antelope & $408.12 \%$ & $40.81 \%$ & $8.2 \% \quad(-)$ \\
\hline Tsessebe & $210.76 \%$ & $21.08 \%$ & $49.25 \% \quad(+)$ \\
\hline Blesbok: White & $134.78 \%$ & $13.48 \%$ & $19.50 \% \quad(-)$ \\
\hline Common & $150.37 \%$ & $15.04 \%$ & $3.84 \% \quad(+)$ \\
\hline Blue wildebeest & $199.19 \%$ & $19.92 \%$ & $0.98 \% \quad(-)$ \\
\hline Bontebok & $215.9 \%$ & $21.59 \%$ & $15.9 \% \quad(+)$ \\
\hline Bushbuck & $284.9 \%$ & $28.49 \%$ & $23.92 \% \quad(+)$ \\
\hline Buffalo (disease free) & $296.52 \%$ & $29.65 \%$ & $53.13 \% \quad(+)$ \\
\hline Duiker & $187.25 \%$ & $18.73 \%$ & $32.07 \% \quad(+)$ \\
\hline Eland (Cape) & $105.8 \%$ & $10.58 \%$ & $13.44 \% \quad(+)$ \\
\hline Gemsbok & $164.02 \%$ & $16.40 \%$ & $4.74 \% \quad(+)$ \\
\hline Giraffe & $91.04 \%$ & $9.10 \%$ & $13.79 \% \quad(+)$ \\
\hline Klipspringer & $143.48 \%$ & $14.35 \%$ & $6.45 \% \quad(-)$ \\
\hline Kudu & $142.51 \%$ & $14.25 \%$ & $16.11 \% \quad(+)$ \\
\hline Lion & $5.42 \%(-)$ & $0.54 \%(-)$ & $54.86 \% \quad(-)$ \\
\hline Nyala & $210.32 \%$ & $21.03 \%$ & $80.33 \% \quad(+)$ \\
\hline Reedbuck & $492.33 \%$ & $49.23 \%$ & $49.65 \% \quad(+)$ \\
\hline Impala & $198 \%$ & $19.8 \%$ & $5.11 \% \quad(+)$ \\
\hline Red hartebeest & $157.17 \%$ & $15.72 \%$ & $8.74 \% \quad(+)$ \\
\hline Mountain reedbuck & $298.80 \%$ & $29.88 \%$ & $22.14 \% \quad(+)$ \\
\hline Burchell's zebra & $81.82 \%$ & $8.18 \%$ & $18.97 \% \quad(+)$ \\
\hline Springbok (common) & $223.73 \%$ & $22.37 \%$ & $6.83 \% \quad(-)$ \\
\hline Heartwater & $74 \%$ & $7.4 \%$ & $30.64 \% \quad(+)$ \\
\hline Black & $203 \%$ & $20.3 \%$ & $13.47 \% \quad(+)$ \\
\hline White & $384.38 \%$ & $38.44 \%$ & $155.2 \% \quad(+)$ \\
\hline Steenbok & $233.40 \%$ & $22.34 \%$ & $53.61 \% \quad(+)$ \\
\hline Black rhinoceros & $53.06 \%$ & $5.31 \%$ & $69.68 \% \quad(+)$ \\
\hline Black wildebeest & $499.78 \%$ & $49.98 \%$ & $5.1 \% \quad(+)$ \\
\hline Sable antelope & $111.90 \%$ & $11.19 \%$ & $9.85 \% \quad(+)$ \\
\hline Fallow deer & $288.28 \%$ & $28.83 \%$ & $1.64 \% \quad(+)$ \\
\hline Grey rhebuck & $826.83 \%$ & $82.68 \%$ & $12.72 \% \quad(-)$ \\
\hline Warthog & $112.36 \%$ & $11.24 \%$ & $8.7 \% \quad(-)$ \\
\hline Ostrich & $105.82 \%$ & $10.58 \%$ & $39.46 \% \quad(+)$ \\
\hline Waterbuck & $129.90 \%$ & $12.00 \%$ & $36.5 \% \quad(+)$ \\
\hline White rhinoceros & $303.66 \%$ & $30.37 \%$ & $39.67 \% \quad(+)$ \\
\hline Total game & $113.53 \%$ & $11.35 \%$ & $14.54 \% \quad(+)$ \\
\hline Total turnover & $600.18 \%$ & $60.02 \%$ & $17.23 \% \quad(+)$ \\
\hline
\end{tabular}

(Source: Eloff. 2002(a):81)

The turnover per year grew from almost R9 $\mathrm{m}$ in 1991 to R105 $\mathrm{m}$ in 2002, with an average growth rate of R38 million per year over 12 years (Table 2).

Live game sales stabilised during the 2001 season but there is a growing demand, especially for scarce game species. The more common species did show signs of price maturity, although new record prices were recorded (Bothma 2002).
The fact that the demand for scarce game species is still on the increase leads to an encouragingly intensive system of production of these animals. It is interesting to note that the prices of male animals are generally lower than those of females, the reason is simply that the latter can be used better for breeding purposes, unless they are of exceptional trophy value. As the number of scarce animals increases, it will eventually lead to a 
Table 4

Trophy hunting statistics 2001

\begin{tabular}{lccccccccc}
\hline Province & EC & NC & FS & KZN & NW & GP & LM & MP & Total \\
\hline Active hunting outfitters & 99 & 33 & 250 & 113 & 99 & 32 & 1972 & 73 & 2671 \\
Active professional hunters & 229 & 179 & 250 & 287 & 261 & 155 & 1972 & 256 & 3589 \\
Clients & 1183 & 537 & 688 & 588 & 465 & 62 & 1644 & 137 & 5304 \\
Total animals & 8941 & 4034 & 3143 & 2531 & 2696 & 185 & 10287 & 429 & 32246 \\
Animals per client & 7.56 & 7.51 & 4.57 & 4.3 & 5.8 & 2.98 & 6.26 & 3.13 & 6.08 \\
Clients per hunting outfitter & 11.95 & 16.27 & 2.75 & 5.2 & 4.7 & 1.94 & 0.83 & 1.88 & \\
Clients per professional hunter & 5.17 & 3 & 2.75 & 2.05 & 1.78 & 0.4 & 0.83 & 0.54 & \\
Total hunting days & 9223 & 4134 & 4425 & 3017 & 3024 & 165 & 28432 & 1112 & 53532 \\
Average. length of hunt (days) & 7.8 & 7.7 & 6.43 & 5.13 & 6.5 & 2.66 & 17.29 & 8.12 & 10.09 \\
\hline
\end{tabular}

WC=Western Cape; EC=Eastern Cape; $\mathrm{NC}=$ Northern Cape; FS=Free State; KZN=KwaZulu-Natal; $\mathrm{NW}=$ North West; $\mathrm{GP}=$ Gauteng; $\mathrm{LM}=$ Limpopo; $\mathrm{MP}=$ Mpumalanga

(Source: PHASA. 2001)

lower market price but they will still have a high trophy value, much higher than their meat value (Eloff 2002a, 2002b). Table 3 indicates the average price increase or decrease of the different game species over the past ten years.

Flack (2002b) indicates that in 1992 there were only nine auctions per year, with 9546 head of game auctioned. This grew to an outstanding 48 auctions in 2000 (17 702 head of game were auctioned), and increased by a further $38 \%$ in 2001. In 2002, it again increased by nearly $21 \%$ with a total of 20022 head of game auctioned (Table 2). The five game species that showed the largest increase in sales in 2000-2001 were as follows; tsessebe $(60.9 \%)$, springbok $(31.2 \%)$, sable antelope $(24.2 \%)$, nyala $(20.2 \%)$ and Burchell's zebra (13.9\%) (Eloff 2002a; Table 3).

\section{Hunting}

Hunting is the biggest generator of income for game farms and for the purpose of this paper can be divided into two types, namely trophy hunting and biltong hunting.

Trophy hunting

According to Table 4 there were 2671 active hunting outfitters/operators and 3589 active professional hunters registered with nature conservation during 2000 and 2001 season. During the same period South Africa received a total of 5304 trophy hunters (excluding biltong hunters), which is 1284 more than during the 1999-2000 season (4 020 trophy hunters).

From Table 4 it is clear that the two leading provinces in trophy hunting in 2001 were Limpopo and Eastern Cape. According to

Table 5

Income of foreign trophy hunters

\begin{tabular}{cc}
\hline Year & Amount generated \\
\hline $1996-4000$ (hunters and non-hunters) & R117 653190 (daily rates and trophy fees) \\
$1997-7500$ (hunters and non-hunters) & R175063050 (daily rates and trophy fees) \\
$1998-7500$ (hunters and non-hunters) & R156871 650 (daily rates and trophy fees) \\
$1999-8604$ (hunters and non-hunters) & R238 158 000 (daily rates and trophy fees) \\
\hline
\end{tabular}


Table 6

Income: trophy hunting and accommodation

\begin{tabular}{ccccc}
\hline Season & $\begin{array}{c}\text { Hunting days } \\
\text { sold }\end{array}$ & $\begin{array}{c}\text { Daily rate } \\
\text { (excluding trophy prize) }\end{array}$ & Total & $\begin{array}{c}\text { Total Animals } \\
\text { and accommodation }\end{array}$ \\
\hline 2000 & 32652 & $\$ 350$ & $\begin{array}{c}\$ 11428200 \\
(\mathrm{R} 85711500)\end{array}$ & $\begin{array}{c}\$ 30818710 \\
(\mathrm{R} 231140325)\end{array}$ \\
2001 & 53532 & $\$ 350$ & $\begin{array}{c}\$ 18,736,200 \\
(\mathrm{R} 224834400)\end{array}$ & $\begin{array}{c}\$ 44325965 \\
(\mathrm{R} 532000000)\end{array}$ \\
\hline
\end{tabular}

(Source: PHASA, 2002)

Table 5, the amount that hunting generated was R117 $\mathrm{m}$ in 1996, and it increased to R237 m in 1999, which includes only trophy hunters that made use of PHASA-registered professional hunters. Therefore, these statistics are regarded as the official trophy hunting statistics.

It is interesting to note that the number of trophy hunters and non-hunters-person who accompany the hunter but does not hunt - remained the same, i.e. 7500, in 1997 and 1998, although the amounts spent were less in 1998. The reason for this may be that the price of game increased from 1997 to 1998. The amount generated then increased from R156 871650 in 1998 to R 238158000 in 1999. It is also important to take into consideration that the rand weakened against the dollar during this period and that only PHASA outfitters were recorded (PHASA 2000).

During the 2001 hunting season, trophy hunters hunted a total of 32246 animals over a total of 53532 hunting days sold (Table 6). When the average daily rate of $\$ 350$ is taken and multiplied by the number of hunting days sold, it adds up to almost R225 million.
The total for accommodation and hunted species combined adds up to R532 million (Table 6). The high demand among foreign trophy hunters for hunting in South Africa might be due to a favourable exchange rate as well as an increase in the wildlife population following the establishment of wellmanaged game farms. Thirty seven percent of all Rowland Ward hunting records have been recorded in South Africa since 1975, as well as $92.9 \%$ of all Safari Club International records (Van Rooyen \& Van Rooyen 2002).

\section{Biltong hunting}

According to Radder et al. (2000) biltong hunters tend to spend the amounts listed in Table 7 when visiting game farms in the Eastern Cape.

Radder et al. (2000) indicated that the average length of stay of biltong hunters is two days and that the average size of a group consists of four hunters. Table 7 clearly illustrates that most money spent on a hunting trip is spent on game, followed by accommodation and refreshments. Hunters tend to spend R300 on daily tariffs and R200 on

Table 7

Biltong hunting expenditure

\begin{tabular}{lr}
\hline Accommodation, meals and refreshments per hunting trip & R200.00 \\
Accommodation expenses per hunting trip considered reasonable & R200.00 \\
Transport costs per hunting trip considered reasonable & R200.00 \\
Daily tariffs considered reasonable per hunting trip & R300.00 \\
Game prices per hunting trip considered reasonable & R1 100.00 \\
Licence expenses considered reasonable & R22.50 \\
\hline
\end{tabular}


transport per biltong hunting trip. Add to this the licence fee and it gives an average total of R2022.50 per biltong hunter per hunting trip (Radder et al. 2000).

Based on the 18000 registered members of the South African Hunters and Game Conservation Association, the total amount generated by them for one hunting trip per year is approximately $\mathrm{R} 36 \mathrm{~m}$. This is just the tip of the iceberg, the reason being that most of the biltong hunters in South Africa are not yet registered members of the latter association and that each province also has its own hunting association, apart from the lattermentioned national body. Therefore, more research still needs to be done to determine the real economic value of biltong hunters to game farm tourism in South Africa (A. van Dyk pers. comm.).

\section{Processed game products}

The potential for the production of venison as a legitimate form of wildlife utilisation, especially in the more arid regions of Africa, has been recognised for a long time (Bothma 2002). Surplus game, usually females, which were not hunted during the season, can be used to supply processed game products to exclusive markets, both overseas and in South Africa. It is important to make these products exotic for the customer. The fact that there is a global movement among humans to live healthier can be an important marketing factor to help sell venison, because venison has a very low fat percentage. Both smoked and fresh processed game products are sold to restaurants and hotels (Gouws 1999; Brits \& Herselman 1988).

When game (venison) is compared with domestic herbivores for meat production, game cannot compete because domesticated herbivores have been genetically bred and selected for many centuries specifically for meat production. The advantage that game has over domestic herbivores is the fact that they offer a wider diversity of products. There are at least 45 types of wild herbivore in southern Africa, of which many occur more or less in the same ecosystem (Bothma
2002). Meat production also generates the lowest income of all the pillars on which game farm tourism is based. The gross income for meat production sales was estimated at R20 million in 2000 (Eloff 2002a).

\section{Ecotourism expenditure}

The literature study confirmed that little research has been conducted on ecotourism expenditure in relation to game farm tourism. It is therefore difficult to determine the real economic value of ecotourism on game farms. However, a pilot study done in the North West Province as part of this paper revealed the spending of tourists to game farms set out in Table 8 .

Research done in the North West Province indicated that the average size of groups travelling to/visiting game farms was three persons and that they tended to stay an average of three days.

It is clear that most money spent (Table 8) by tourists was on accommodation and transport per ecotourist group per trip.

The least money was spent on clothing, tobacco, medicine, toiletries and recreation activities. The reason for this is that game farms tend not to have tourist or curio shops where visitors can spend money. Recreation spending is also low as it was found that

Table 8

Tourist spending

\begin{tabular}{lr}
\hline Category & Amount spent \\
\hline Accommodation & R1699.38 \\
Entrance fee & R18.21 \\
Restaurants & R408.36 \\
Food & R335.77 \\
Beverages & R171.63 \\
Tobacco products & R45.30 \\
Clothing and Shoes & R411.00 \\
Transport & R81.00 \\
Recreation & R1.80 \\
Medicine & R 6.20 \\
Toiletry & R3 192.65 \\
\hline Total &
\end{tabular}


only few game farms made provision for recreational activities.

The average spending per group ( 3 persons) for three days is R3 192.65. Each person would then spend an average of R1 064.21 per trip. Hence one person spends on average R354.73 per day over a three-day period, so that if 100000 tourists took one trip to a game farm during a year and spent R1 064.21 per trip, this would add up to approximately R106 million. This clearly indicates the economic value of ecotourism to game farm tourism.

\section{Conclusion}

The purpose of this paper was to determine the economic value of game farm tourism. Even though this was the purpose, one cannot but mention also the conservation value of game farm tourism. The latter entails more land for consumptive utilisation, even though some conservationists still cannot perceive the contribution of the consumptive utilisation of game in the form of hunting to both the economy and the tourism industry in South Africa. Something else that also has to be kept in mind is that as a consequence more breeding centres are established throughout South Africa, which has a positive effect in terms of the number of species available.

This paper also showed that even though there are gaps in the statistics of some of the aspects (pillars) of game farm tourism, the latter nevertheless has a significant economic value, as can be seen from the 2000 statistics:

\begin{tabular}{lr} 
Hunting (trophy and biltong) & R568 m \\
Game sales & R180 m \\
Game products & R20 m \\
Ecotourism & R106 m \\
\hline Total & R874 m
\end{tabular}

Over and above the fact that game farm tourism in South Africa generated approximately R874 m, the 7000 game farms also employ approximately 63000 people. In order to grow this sector, this research recommends that game farm owners/managers must, as far as possible, implement all four pillars. The ecotourism component should be exploited and opportunities where tourists can spend more money should be created. This implies, for example, providing recreational activities, restaurants and the selling of curios and services. It is also a recommendation of this paper that more research be done, especially into the value of ecotourism and into biltong hunting needs.

\section{Acknowledgements}

We thank Dr Andrea Saayman for the assistance given.

\section{References}

ANON. 1998. Tourism leading global economic driver of the 21st century. Satour News 3, December.

Botнma, J. DU P. 2002(a). Some economics of wildlife ranching. Wildlife group symposium on Game Ranch Management, S.A. Veterinary Association, Onderstepoort, 1-2 November 2002

Brits, D. \& W. Herselman. 1988. Wildbenutting. Fauna \& Flora 44:18-24.

CoOper, C., J. Fletcher, D. Gilbert \& S. Wanhill. 1993. Tourism principles \& practice. London: Pitman.

Eastern Cape Province (South Africa). 1974. Ordonnansie op natuur- en omgewingsbewaring, no. 19 van 1974. Kaapstad.

EbedEs, H. 2002. Preface. In: Ebedes, H., B. ReIlly, W. van Hoven \& B. Penzhorn (eds.). Sustainable utilisation-conservation in practice. Proceedings of the 5th International Wildlife Ranching Symposium 2001. Pretoria.

ElofF, T. 1999. Professionalisme in die wildbedryf. KLK Nuus 29(1): 9.

Eloff, T. 2000. Die omvang van die wildbedryf in Suid-Afrika. Potchestroom: PU vir CHO.

ElofF, T. 2002(a). The economic realities of the game industry in South Africa. In: Ebedes, H., B. Reilly, W. van Hoven \& B. Penzhorn (eds.). Sustainable utilisation-conservation in practice. Proceedings of the 5th International Wildlife Ranching Symposium 2001. Pretoria.

ElOFF, T. 2002(b). Boerdery met skaars groter spesies. Game \& Hunt 8(2): 21.

ElOFF, T. 2003. Gemiddelde wildveilingpryse 2002. Game \& Hunt 9(2): 21. 
ERASMUS, S.D. 2000. Die ekonomiese lewensvatbaarheid van ' $n$ wildvleisbewerkingsaanleg in Suid-Afrika. M.Com. verhandeling, Potchefstroomse Universiteit vir CHO.

FLACK, P.H. 2002. The conservation revolution. Game \& Hunt 8(10): 29, 31,33.

Fox, T. \& P. DU Plessis. 2000. Hunting in South Africa. Africa indigo - in touch with the African renaissance 3(3): 40.

Fraser, J. 1999. The travel industry. 2nd ed. New York: Van Nostrand Reinhold.

Gouws, A. 1999. Smul gevaar van surpluswild weg. Landbouweekblad 1124: 16-17.

GCIS (Government Communication and Information System). 1998. South Africa Official Yearbook. Cape Town: Rustica.

GCIS (Government Communication and Information System). 1999. South Africa Official Yearbook. Cape Town: Rustica.

KerzNER, S. 1995. Foreword. In: BenNetT, J.A., (ed.). Managing tourism services. Pretoria: Van Schaik.

KocH, E. 1995. Solutions - conservation and rural community development in South Africa. Optima 41(2): 35 .

PhASA. 2000. South African Hunting Statistics. Pretoria: Professional Hunters Association of South Africa.

PhasA. 2001. South African Hunting Statistics. Pretoria: Professional Hunters Association of South Africa.

PHASA. 2002. South African Hunting Statistics. Pretoria: Professional Hunters Association of South Africa.

RAdDER, L. \& P. van NiekerK \& A. NAgel. 2000. Matching the hunting experience stage by selected farmers in the Eastern Cape to the value expectations of hunters: research report. Port Elizabeth: Port Elizabeth Technikon.

Shaw, S. \& A.M. WiLliams. 1994. Critical issues in tourism: a geographical perspective. Oxford: Blackwell.
Thornton, G. \& K. Feinstein. 2002. Tourism talk: a summary of the most important data and statistics relevant to the regional tourism industry. Journal of Southern African Tourism 1(3): 4853.

VAN Der Merwe, P. \& M. SAAYMAN. 2002. Managing game farms from a tourism perspective. Potchefstroom: Leisure C Publications.

VAN DER WALT, J. 2002. Proliferation of game ranches. Game \& Hunt (10)8: 7, Oct.

VAN RoOyen, N. \& J. van RoOyen. 2002. Handling and measuring trophies. Pp. 513-546. In: ВотнMA, J. DU P., (ed.). Game ranch management. 4th ed. Pretoria: Van Schaik.

VAN WYK, M.L. 1995. Die invloed van ekotoerisme op lewenskwaliteit in ontwikkelende gemeenskappe: 'n ontwikkelingskommunikasieperspektief. M.Com. verhandeling. Potchefstroomse Universiteit vir CHO.

VAN ZYL, J. 2000. 'n Boer maak 'n plan: wildbedryf: fokus. Finansies \& Tegniek: 22. Apr. 14.

World BANK. 1998. World Bank Group and World Tourism Organisation examine role of tourism in development. http://www.world-tourism.org/ pressrel/WBWTO [Date of access: 3 Dec. 1998].

WTO (World Tourism Organisation). 1998. Results prove strength of tourism. http:/www.worldtourism.org/newslett/febmar99/1998results [Date of access: 19 Mar. 1999].

WTO (World Tourism Organisation). 2001(a). WTO long-term forecast tourism 2020 vision. [Web:] http://www.world-tourism.org/market research/data/forecast.html [Date of access: 19 Mar. 1999].

WTO (World Tourism Organisation). 2001(b). Africa to triple tourist numbers. http://www. world-tourism.org/newsroom/releases/more releases/R010607.html [Date of access: 19 Mar. 1999]. 